\title{
ALTERATIONS OF THE STEM-LIKE PROPERTIES IN THE BREAST CANCER CELL LINE MDA-MB-231 INDUCED BY SINGLE PULSED DOXORUBICIN TREATMENT
} \author{
and Edvīns Miklaševičs \\ Institute of Oncology, Rīga Stradiṇš University, 13 Pilsoṇu Str., Rīga, LV-1002, LATVIA \\ \# Corresponding author, valdis.pirsko@ rsu.Iv
}

Valdis Pirsko\#, Inese Čakstiṇa, Dina Nitiša, Marija Samoviča, Zanda Daneberga,

Communicated by Jānis Gardovskis

\begin{abstract}
Development of chemoresistance remains a significant limitation for the treatment of cancer and contributes to recurrence of the disease. Both intrinsic and acquired mechanisms of chemoresistance are characteristics of cancer stem cells (CSCs) or stem-like cells (SLCs). The aim of the study was to assess the stem-like properties in the breast cancer cell line MDA-MB-231 during and after pulsed treatment with doxorubicin (DOX) in comparison to the untreated controls. The experimental cultures were exposed to therapeutic concentration of DOX for 48 hours (treatment cultures), and subcultured to post-treatment cultures 24 hours after the removal of DOX. Stemlike properties of the cellular populations in the treatment and post--treatment cultures were assessed by the expression of the stem-cell marker genes (CD24, CD44, ITGA6, ITGB1, POU5F1, NANOG, ALDH1A1), colony-formation efficiency, growth rates, and sensitivity to DOX, 5-fluorouracil (5FU), cisplatin (CIS), and vinblastine (VBL). Exposure to DOX induced formation of giant polyploid cells that persisted in the post-treatment culture. The recovery period was characterised by a decrease in the proliferation rate, viability, and cellular adherence. The post-treatment cultures displayed decreased sensitivity to DOX and increased sensitivities to 5FU, CIS, and VBL. Cells treated with DOX displayed increased expression levels of CD24, CD44, and ALDH1A, while their expression levels at least partially normalised in the post-treatment culture. The post-treatment cultures demonstrated significantly increased colony-formation ability. During treatment with sub-lethal levels of doxorubicin and during the acute recovery period, the survival mechanisms in the breast cancer cell line MDA-MB-231 may be mediated by formation of the cellular population with stem-like properties.
\end{abstract}

Key words: chemotherapy resistance, cancer stem-like cells (cSCLs), stem-cell marker genes.

\section{INTRODUCTION}

Chemotherapy is a significant modality of cancer management used alone or in combination with other therapies to treat various tumours (Gottesman et al., 2001; Holohan et al., 2013). Tumour cell resistance is a major cause of chemotherapy failure, and therefore it constitutes a major problem in cancer therapy (Rivera and Gomez, 2010; Holohan et al., 2013). Tumour chemoresistance can be intrinsic or acquired (adaptive). Intrinsic resistance manifests as a low sensitivity of tumour cells to the chemotherapeutic compound due to pre-existing resistance mechanisms, whereas acquired resistance develops in chemo-sensitive tumour cells during treatment (Holohan et al., 2013). Cancer recur- rence after chemotherapy may be a result of the regeneration of the cancer cell population by a few cancer cells that have become less sensitive to the cytotoxic compound during therapy (Dean et al., 2005). Another hypothesis for cancer resistance is based on tumour heterogeneity, i.e. chemotherapy may exert a selection pressure on naturally resistant cells that eventually are capable of restoring the cancer cell population (Holohan et al., 2013). This mechanism may involve cancer stem cells (CSCs) that possess an intrinsic potential to escape the effects of chemotherapy. The transfer of chemoresistance properties from CSCs or similar cells to daughter cells has been observed in several studies (Dean et al., 2005; Moitra et al., 2011). The survival of some cells under selective pressure of one chemotherapy compound 
may result in chemoresistance to other structurally distinct chemotherapeutic agents with different modes of action (i.e., multidrug resistance). Multi-drug resistant cells have been associated with increased tumour aggressiveness, recurrence, and metastasis (Saxena et al., 2011), therefore studies of chemoresistance mechanisms may allow for the development of effective treatment efficiency biomarkers and new therapeutic approaches to cancer therapy (Tegze $e t$ al., 2012).

Doxorubicin is an anthracycline cytotoxic compound that has been used in chemotherapy for decades (Cortós-Funes and Coronado, 2007; Xiang et al., 2017). Doxorubicin intercalates between bases in DNS, inhibiting human DNA topoisomerase 2- $\alpha$ and inducing the formation of potentially cytotoxic reactive oxygen species (Gewirtz, 1999). It enters the cell via a passive diffusion mechanism, and the resulting intracellular concentration exceeds the extracellular concentration by 50-100 fold (Cortós-Funes and Coronado, 2007). Depending on dosage levels doxorubicin-induced DNA damage leads to the arrest of the cell cycle in G1 and G2 phases, apoptosis (Gewirtz, 1999) or senescence (Smith et al., 2006). Treatment failure due to acquired resistance has been observed also in doxorubicin treated patients (Smith et al., 2006). The main mechanisms mediating tumour cell resistance to doxorubicin are: (i) increased expression of drug transporter proteins, (ii) modifications in target molecule(s), and (iii) altered cell death signalling (Cox and Weinman, 2016).

According to the clonal evolution theory, a tumour consists of genetically and phenotypically different cell populations (Nowell, 1976). Tumour heterogeneity provides cellular diversity for resistance, self-renewal capability and growth adjustments (Liang et al., 2010).

Tissue stem cells possess properties of self-renewal and virtually unlimited proliferation potential, maintain the pool of undifferentiated tissue cells, and their differentiation potential may be induced by certain stimuli (Rajaraman et al., 2006). CSCs possess similar properties (Achuthan et al., 2011). Although cancer stem cell theory is a controversial concept of cancer biology, experimental evidence for the existence of stem cells or stem-like cells in tumours is extensive. Recently, the expansion of CSCs subpopulations in cell culture has been associated with the stress-induced (hypoxia, chemotherapy, radiotherapy) development of polyploid, multinucleated giant cells that are capable of replenishing the tumour cell population (Mirzayans et al., 2018). CSCs have been characterised by a particular pattern in the expression of several marker genes, e.g., ALDH1A, CD24, $C D 44, C D 133$, and so called "stemness" genes of normal stem cells, e.g., SOX2, OCT3/4, NANOG (Liu et al., 2013; Zhang et al., 2013), as well as markers related to epithelialmesenchymal transition, like ITGB1, ITGB3, and ITGA6 (Brooks et al., 2016).

Experimental studies and clinical trials have shown intrinsic resistance of CSCs to chemo- and radiotherapy. Positive selection for CSCs during therapy leads to recurrence of more aggressive and more resistant tumours with increased metastatic potential (Vinogradov and Wei, 2012).

In this study, we assess the dynamics of stem-like properties in the breast cancer cell line MDA-MB-231 after single pulsed treatment with doxorubicin.

The aim of the study was to evaluate the alterations of stem-like properties in a triple-negative breast cancer cell line MDA-MB-231 during and after pulsed treatment with the cytotoxic agent doxorubicin (DOX) in comparison to untreated controls.

\section{MATERIALS AND METHODS}

Cell culture maintenance. The triple negative breast cancer cell line MDA-MB-231 (ATCC HTB®-26) was cultured in a DMEM/F12 (1:1) (Thermo Fisher Scientific) medium with $10 \%$ foetal bovine serum (FBS) (Sigma Aldrich); $1 \mathrm{x}$ penicillin/streptomycin (Sigma Aldrich) in a humidified atmosphere containing $5 \% \mathrm{CO}_{2}$ at $37{ }^{\circ} \mathrm{C}$. TripLE (ThermoFisher Scientific) was used for cell subculturing. During passaging cell counts and cellular viability were determined in a haemocytometer chamber (Improved Neubauer) with exclusion dye Trypan Blue (Sigma Aldrich).

Pulsed treatment with doxorubicin. After treatment group cultures (duplicate) had reached $50-60 \%$ confluence. They were pulse-treated with $0.26 \mu \mathrm{M}$ doxorubicin (DOX) (Ebewe Pharma) for $48 \mathrm{~h}$ (treated or DOX cultures). Then the drug containing the medium was removed, and the cultures were rinsed with Dulbecco's PBS (D-PBS) (Sigma Aldrich) and further cultured in a fresh drug-free medium for another $24 \mathrm{~h}$ prior to passaging to post-treatment $(\mathrm{DOX}+1)$ cultures. Untreated cultures were grown in parallel as a control (two sequential cultures: Control and Control+1). For control, Control+1 and DOX cultures cells were seeded at a density of $3.5 \times 10^{3} / \mathrm{cm}^{2}$ in $75 \mathrm{~cm}^{2}$ flasks (Sarstedt); reseeding after pulsed treatment with doxorubicin (post-treatment cultures) was performed at a density of $6.0 \times 10^{3} / \mathrm{cm}^{2}$ in $75 \mathrm{~cm}^{2}$ flasks.

Sulforhodamine B (SRB) assay. Whole-well surrogate assay sulforhodamine B (SRB) assay was performed according to Skehan et al., 1990 and Vichai et al., 2006. In brief, at pre-specified time-points cells on 96-well plates were fixed with $10 \%$ (wt/vol) tricloroacetic acid (Sigma Aldrich) (final concentration), rinsed four times under slowly running tap water and air-dried. Then plates were incubated with a $4 \mathrm{mg} / \mathrm{ml} \mathrm{SRB} \mathrm{(Sigma} \mathrm{Aldrich)} \mathrm{solution} \mathrm{in} 1 \%$ acetic acid (vol/vol) (Sigma Aldrich) for $30 \mathrm{~min}$ and quickly rinsed six times with $1 \%$ acetic acid. Plates were air-dried and $10 \mathrm{mM}$ Tris base solution ( $\mathrm{pH}$ 10.5) (AppliChem) was added. Plates were shaken on an orbital shaker for $10 \mathrm{~min}$ and the solution was transferred to a fresh plate. Absorbance $(A)$ was measured at $565 \mathrm{~nm}$ in a microplate reader (Infinite M200 PRO, Tecan). For each time-point at least six simultaneous technical replicates of SRB assay were performed, if not mentioned otherwise. The $A$ value at each 
time-point was calculated as an average of the technical replicates after discarding extreme outlying values (more or less than three interquartile ranges from upper and lower quartile, respectively).

Cell growth curves and population doubling times (PDTs). To obtain cell growth curves, cells were plated on 96-well plates (Cell+, Sarstedt) at a density of $5 \times 10^{3}$ cells per well $\left(5 \times 10^{4} / \mathrm{cm}^{2}\right)$. Cell numbers were measured for 8 days at $24 \mathrm{~h}$ intervals starting $24 \mathrm{~h}$ after initial plating $(8$ time-points, 12 technical repeats). There were at least eight technical replicates for each time-point. Surrogate estimates for total cell numbers at each time-point were determined as absorbance values by a whole-well sulforhodamine B (SRB) assay. Population doubling times (PDTs) were derived from the exponential growth phase of the curves, taking $48 \mathrm{~h}\left(\mathrm{t}_{0}\right)$ and $96 \mathrm{~h}\left(\mathrm{t}_{1}\right)$ time-point values (time difference $48 \mathrm{~h})$ as starting $\left(\mathrm{A}_{48 \mathrm{~h}}\right)$ and end $\left(\mathrm{A}_{96 \mathrm{~h}}\right)$ values for calculation (Freshney, 2011):

$P D T=\frac{48 h}{\log _{2}\left(A_{96 h}\right)-\log _{2}\left(A_{48 h}\right)}$

Cytotoxicity assay. The sensitivity of the control and posttreatment $(\mathrm{DOX}+1)$ cultures to the chemotherapeutic substances was measured by a cytotoxicity endpoint SRB assay. The tested compounds were doxorubicin (DOX), 5fluorouracil (5FU) (both from Ebewe Pharma), cisplatin (CIS) (Accord Healthcare Ltd.), and vinblastine sulphate (VBL) (Sigma Aldrich). Cells for the assay were plated on 96-well plates at a density of $5 \times 10^{3}$ cells per well $\left(5 \times 10^{4} / \mathrm{ml}\right)$ during passaging of the respective culture. The concentration ranges and the particular concentrations for tested substances were chosen on the basis of pilot experiments (not reported) and are shown in Table 1. Tested substances in the respective concentrations (in six technical repeats) were added to the cells $48 \mathrm{~h}$ post-seeding, and the length of exposure for the cytotoxicity assay was $48 \mathrm{~h}$. At the beginning of exposure non-treated baseline control plate cells $(\mathrm{t}=0 ; 60$ technical repeats) were fixed for SRB assay, and at the end of the exposure non-treated positive control plate cells ( $\mathrm{t}=48 \mathrm{~h}$; 60 technical repeats) were fixed for SRB assay.

To estimate inhibitory concentration $50 \%\left(\mathrm{IC}_{50}\right)$ and growth rate $50 \%\left(\mathrm{GR}_{50}\right)$ the dose-response curves obtained in cytotoxicity assay results were analysed with the use of statistical software R package GRmetrics (Hafner et al., 2016, https://www.R-project.org). The value of $\mathrm{GR}_{50}$ is normal- ised and does not depend on the division rates of cultures during the cytotoxicity assay (Hafner et al., 2016).

Long-term colony formation assay. During passaging cells were seeded on 24-well plates (1 ml/well) (Cell+, Sarstedt) in triplicates at a density of 20 cells per well. After 11 days, the cell colonies on the plate were fixed using $10 \%$ TCA, stained with $0.01 \%$ (wt/vol) crystal violet (Serva) and the colonies ( $\geq 50$ cells) were counted manually. Data were analysed using statistical software R and RStudio (Anonymous, 2018; https://cran.r-project.org). Colony forming ability (\%) was estimated by the equation:

$Y=\frac{K}{20} * 100$,

where Y - colony forming ability (\%), $\mathrm{K}$ - number of colonies/well, 20 - number of seeded cells/well. The average values and standard deviations for each culture were calculated. The statistical significance for colony-forming unit counts in different cultures was determined by the Student's t-test.

qPCR and gene expression analysis. Isolation of RNA from $1 \times 10^{6}$ cells was performed using TRIzol reagent (Thermo Fisher Scientific) according to the manufacturer's protocol. Total concentration of RNA was determined by a NanoDrop 1000 spectrophotometer (Thermo Fisher Scientific). The quality of RNA was determined on $2 \%$ agarose gel electrophoresis. After RNA treatment with DNaseI (Sigma Aldrich) and purification using NucleoSpin XS (Macherey Nagel), $2 \mu \mathrm{g}$ of RNA was used for cDNA synthesis with a High-Capacity cDNA Reverse Transcription kit (Thermo Fisher Scientific). The quality of synthesised cDNA was assessed using a FIREPol DNA polymerase PCR kit (Solis BioDyne) with housekeeping genes ACTB1 and I8SRNA.

We used a $5 \mathrm{ng} /$ reaction of cDNA in triplicate for qPCR (real-time PCR) with 5x HOT FIREPol EvaGreen qPCR Plus (ROX) kit (Solis BioDyne). The qPCR was performed for 40 cycles with the following conditions: $95 \mathrm{C}$ for $15 \mathrm{~s}$, $58 \mathrm{C}$ for $30 \mathrm{~s}$ and $72 \mathrm{C}$ for $30 \mathrm{~s}$ on a real-time PCR cycler Viia7 (Thermo Fisher Scientific). The oligonucleotide sequences are shown in Table 2.

Quality control was performed for each gene in technical triplicate followed by analysis of data. Quality control included the analysis of product melting and amplification curves. If there was more than one peak in the melting

Table 1

CONCENTRATION RANGE AND CONCENTRATIONS OF CHEMOTHERAPEUTIC COMPOUNDS FOR CYTOTOXICITY ASSAY

\begin{tabular}{l|c|l}
\hline $\begin{array}{c}\text { Chemotherapeutic } \\
\text { compound }\end{array}$ & $\begin{array}{c}\text { Concentration } \\
\text { range }\end{array}$ & \multicolumn{1}{c}{ Concentrations used for cytotoxicity assay, mol/1 [M] } \\
\hline Doxorubicin & $0.25 \mathrm{nM}-25 \mu \mathrm{M}$ & $2.5 \times 10^{-5}, 2.5 \times 10^{-6}, 1.75 \times 10^{-6}, 1.0 \times 10^{-6}, 2.5 \times 10^{-7}, 1.75 \times 10^{-7}, 1.0 \times 10^{-7}, 2.5 \times 10^{-8}, 2.5 \times 10^{-9}, 2.5 \times 10^{-10}$ \\
5-fluorouracil & $0.25 \mu \mathrm{M}-5 \mathrm{mM}$ & $5.0 \times 10^{-3}, 2.5 \times 10^{-3}, 1.0 \times 10^{-3}, 5.0 \times 10^{-4}, 2.5 \times 10^{-4}, 1.75 \times 10^{-4}, 1.0 \times 10^{-4}, 2.5 \times 10^{-5}, 2.5 \times 10^{-6}, 2.5 \times 10^{-7}$ \\
Cisplatin & $25 \mathrm{nM}-250 \mu \mathrm{M}$ & $2.5 \times 10^{-4}, 1.75 \times 10^{-4}, 1.0 \times 10^{-4}, 2.5 \times 10^{-5}, 1.75 \times 10^{-5}, 1.0 \times 10^{-5}, 2.5 \times 10^{-6}, 1.75 \times 10^{-6}, 2.5 \times 10^{-7}, 2.5 \times 10^{-8}$ \\
Vinblastine & $0.25 \mathrm{nM}-17.5 \mu \mathrm{M}$ & $1.75 \times 10^{-5}, 1.0 \times 10^{-5}, 2.5 \times 10^{-6}, 1.75 \times 10^{-6}, 2.5 \times 10^{-7}, 2.5 \times 10^{-8}, 1.75 \times 10^{-8}, 1.0 \times 10^{-8}, 2.5 \times 10^{-9}, 2.5 \times 10^{-10}$
\end{tabular}


OLIGONUCLEOTIDE SEQUENCES USED FOR REAL TIME qPCR

\begin{tabular}{|c|c|c|}
\hline Gene symbol & Sequence $\left(5^{\prime} \rightarrow 3^{\prime}\right)$ & GenBank accession nb. \\
\hline$A C T B$ & $\begin{array}{l}\text { F: TCCCTGGAGAAGAGCTACG } \\
\text { R: GTAGTTTCGTGGATGCCACA }\end{array}$ & NM_001101.5 \\
\hline RNA18SN1 & $\begin{array}{l}\text { F: CGGCTACCACATCCAAGGAA } \\
\text { R: GCTGGAATTACCGCGGCT }\end{array}$ & NR_145820.1 \\
\hline RNA28SN3 & $\begin{array}{l}\text { F: CAGGGGAATCCGACTGTTTA } \\
\text { R: ATGACGAGGCATTTGGCTAC }\end{array}$ & NR_146154.1 \\
\hline$A L D H 1 A 1$ & $\begin{array}{l}\text { F: GGGGGCGACTATTATACAAG } \\
\text { R: ATTGGTATTGTACGGCCCTG }\end{array}$ & NM_000689.5 \\
\hline$C D 24$ & $\begin{array}{l}\text { F: TGCTGCTGGCACTGCTCCTA } \\
\text { R: CCACGAAGAGACTGGCTGTTGA }\end{array}$ & NM_013230.3 \\
\hline CD44 & $\begin{array}{l}\text { F: GAAGGGCACGTGGTGATTCC } \\
\text { R: CAAAGGCATTGGGCAGGTCT }\end{array}$ & NM_000610.3 \\
\hline ITGA6 & $\begin{array}{l}\text { F: CCACGTCAGAAAGCAAGGA } \\
\text { R: CCCAAAGATGTCTCGGGATT }\end{array}$ & NM_001079818.3 \\
\hline ITGBI & $\begin{array}{l}\text { F: GGCCTCTGGGCTTTACGGAGGA } \\
\text { R: CCTGCACGCGCCACACTCAA }\end{array}$ & NM_002211.4 \\
\hline$N A N O G$ & $\begin{array}{l}\text { F: ACATGCAACCTGAAGACGTGTG } \\
\text { R: CATGGAAACCAGAACACGTGG }\end{array}$ & NM_024865.4 \\
\hline POU5F1 & $\begin{array}{l}\text { F: ACATCAAAGCTCTGCAGAAAGAACT } \\
\text { R: CTGAATACCTTCCCAAATAGAACCC }\end{array}$ & NM_002701.6 \\
\hline
\end{tabular}

curve, the product was tested using agarose gel electrophoresis. Data from samples containing more than one correct product and from samples that did not reach the threshold of amplification were excluded from further analysis. Criteria for data quality were: $\mathrm{Ct}$ values that were located more than three SDs from the average value of the triplicate were not included in the analysis. As a threshold values for expression, the gene was assumed to be expressed if the average $\mathrm{Ct}$ value was below 35. The transcription level of the gene in each culture was normalised against endogenous control genes ( $A C T B, 18 S$ rRNA), thus obtaining $\mathrm{dCt}$ values. Changes in gene expression were expressed relative to the control cultures (without DOX treatment) using the $\mathrm{ddCt}$ value and calculating the number of relative changes (RQ) (Livak and Schmittgen, 2001). If Ct was undetermined, a value of 41 was used. A heat map was generated using the statistical software $\mathrm{R}$ programme 3.5.1. package gplots (Anonymous, 2018; https://cran.r-project.org). The statisti- cal significance of the expression changes was determined by a two-tailed unpaired t-test using six values in each group.

\section{RESULTS}

Changes in cell morphology and proliferation rate after pulsed treatment with doxorubicin. After pulsed treatment of breast cancer cell line MDA-MB-231 culture with $0.26 \mu \mathrm{M}$ doxorubicin for $48 \mathrm{~h}$ the proportion of the giant cells in DOX cultures increased in comparison to controls (Fig. 1). Treatment with DOX resulted in lower cell counts and viability at the passaging in the DOX cultures vs. control cultures (viability in DOX treated cultures and controls of $86.6 \%$ and $90-95 \%$, respectively).

The growth of the post-treatment $(\mathrm{DOX}+1)$ cultures displayed two distinct phases: during the recovery period, the

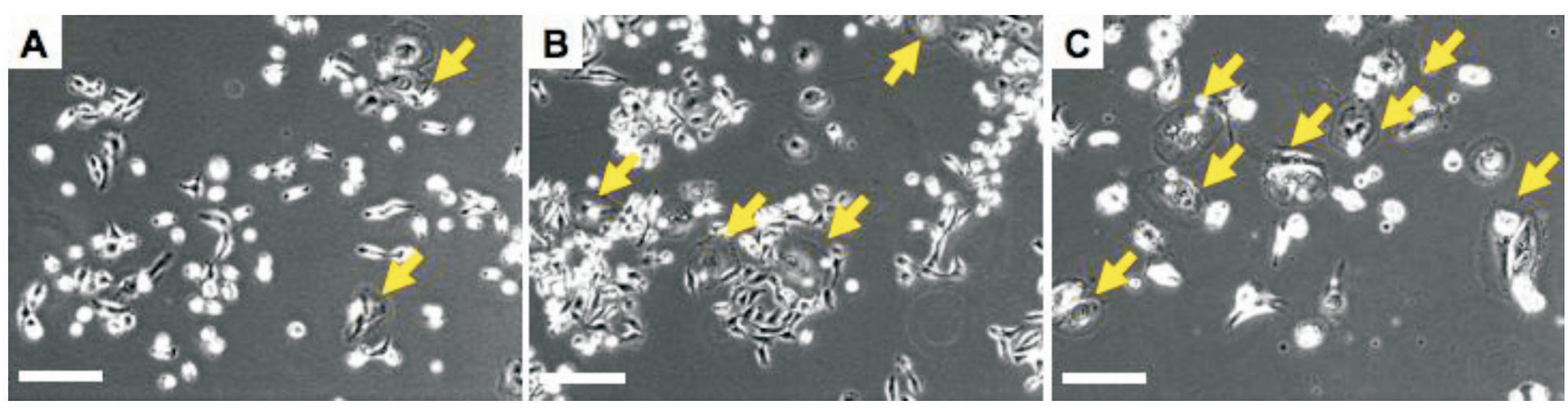

Fig. 1. Cellular morphology of MDA-MB-231 before and after pulsed treatment with $0.26 \mu \mathrm{M}$ doxorubicin (cultivation days 2 to 4 ). A, control cultures; B, treated (DOX) cultures $48 \mathrm{~h}$ after exposure to doxorubicin; C, post-treatment (DOX+1) cultures, i.e. one passage after doxorubicin treatment. Arrows indicate giant cells. Magnification $100 \times$, scale bar $200 \mu \mathrm{m}$. 
culture contained an increased proportion of large cells and dying cells, while further growth was characterised by colony forming and regeneration of the cellular population (Fig. 2).

During the first two growth weeks, the DOX+1 cultures displayed mostly dying (confluence dropped from $40 \%$ to 5-10\%) cells. On day 10 after passaging to DOX+1 culture, the formation of new colonies containing morphologically distinct, smaller cells was observed (Fig. 3, d10, green arrow), and further growth was characterised by increased forming of colonies and regeneration of the cellular population (Fig. 3).

Also, the morphology of the cells in the treated culture differed from the control cultures, and displayed heterogeneity, including mesenchymal, epithelial, giant and neuronal-type cells (Fig. 4).

To assess changes of growth parameters in post-treatment cultures, growth curves were generated and population doubling times (PDTs) were estimated (Fig. 5).
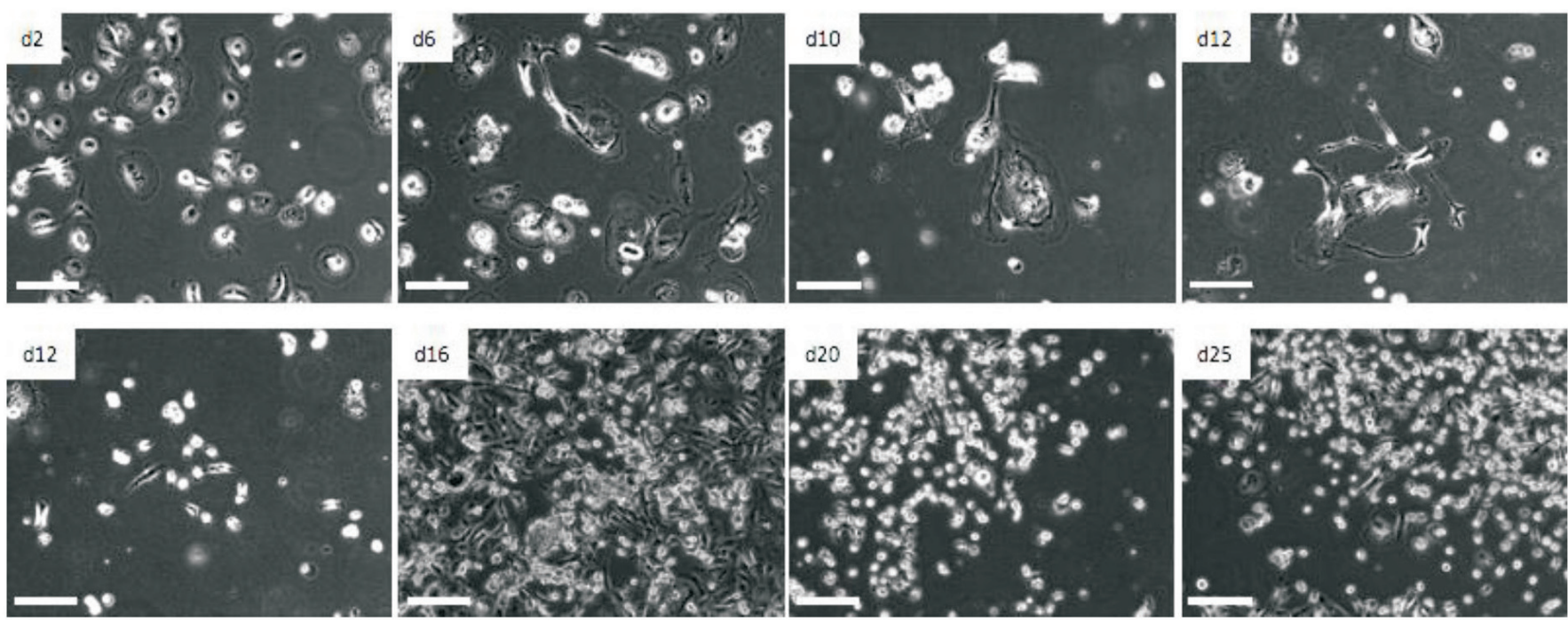

Fig. 2. The dynamics of cellular appearance in post-treatment $(\mathrm{DOX}+1)$ cultures of MDA-MB-231 cells. The upper line $(\mathrm{d} 2-\mathrm{d} 12)$ demonstrates increased cellular size and cell death, the lower line (d12 - d25) displays colony formation and regeneration of the cellular population. $\mathrm{d} 2-\mathrm{d} 25$ indicate the day of cultivation. Magnification 100x, scale bar $200 \mu \mathrm{m}$.
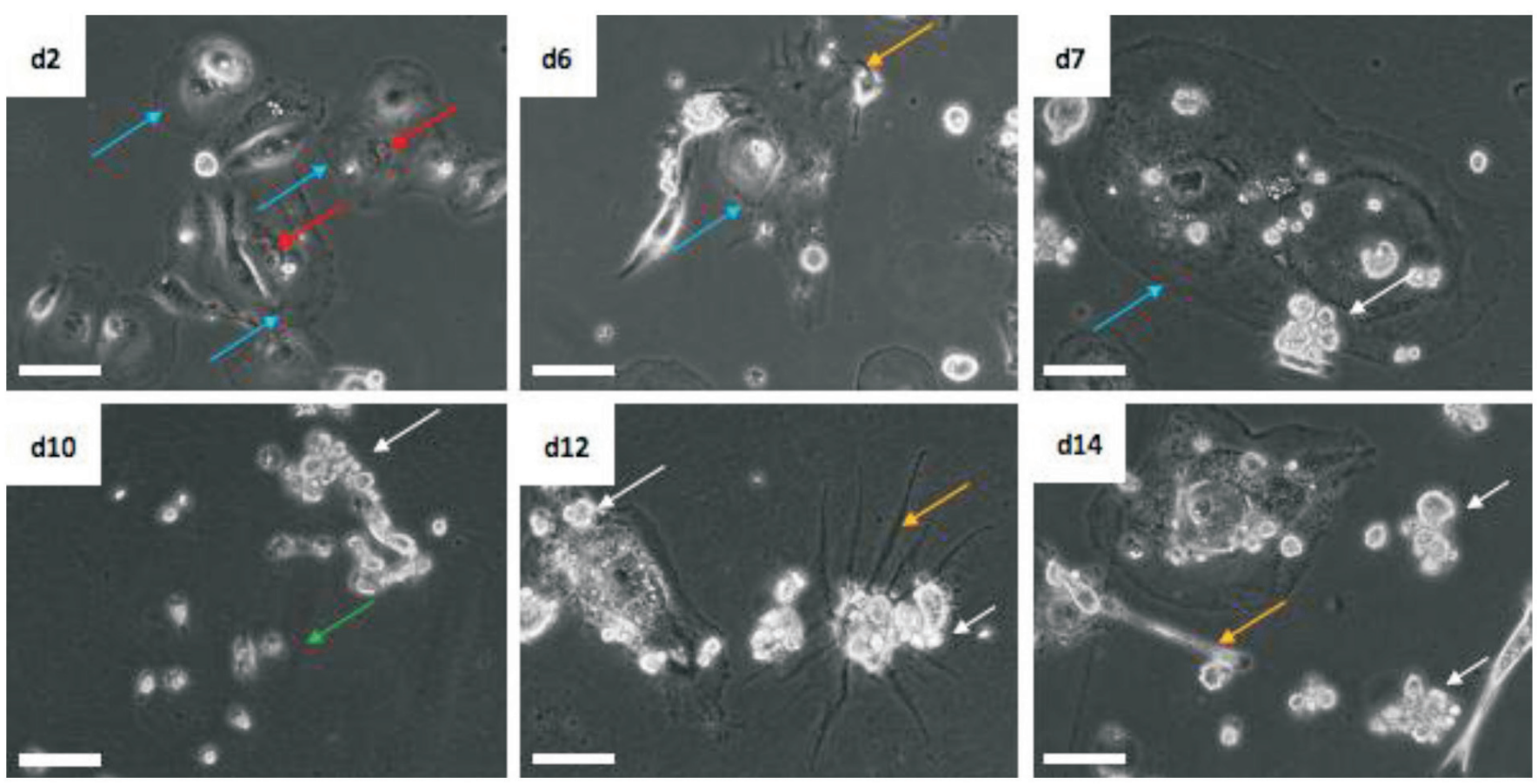

Fig. 3. Heterogeneity of cell morphology in post--treatment (DOX+1) culture of MDA-MB-231 during the acute recovery phase (until day 10 after treatment). d2 - d14 indicate the day after passaging of doxorubicin treated culture. Coloured arrows show diverse morphological characteristics: semi-adherent and floating aggregates of cells and/or cellular debris (white), cells with more than one nucleus (red), cellular extensions (orange), cells displaying features of incomplete mitosis or fusion (blue), new cell colony of cells (green). Magnification 200×, scale bar $100 \mu \mathrm{m}$. 

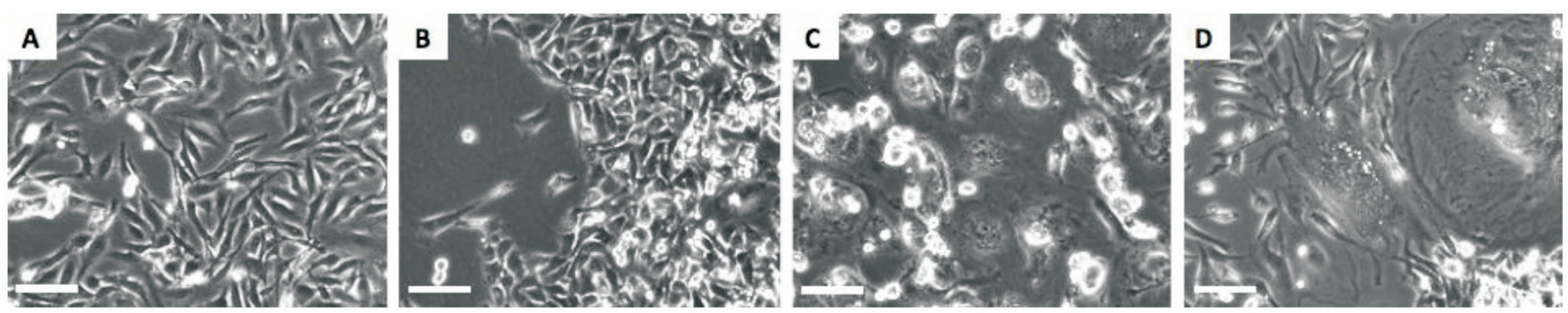

Fig. 4. Heterogeneity of cellular morphology in post-treatment (DOX+1) culture of MDA-MB-231 during re-growth phase of the culture (after day 10 of the treatment). Cells were mostly spindle-like (mesenchymal) type; picture (A), some epithelial cell (B) and giant cell colonies (C). Round, irregular (D) and neuronal-type giant cells could still be observed. Magnification 200x, scale bar $100 \mu \mathrm{m}$.

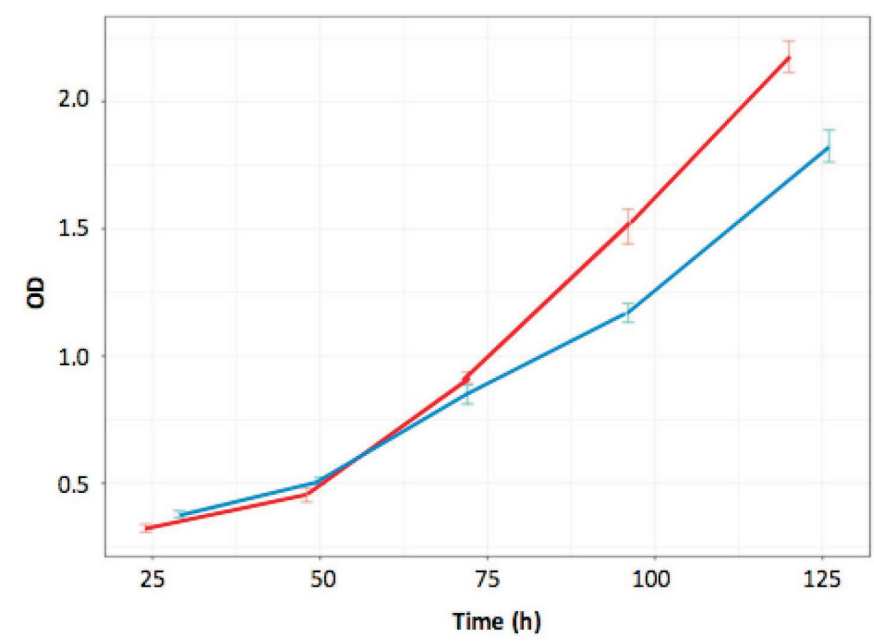

Fig. 5. Growth curves of control (red) and post--treatment (DOX+1) (blue) MDA-MB-231 cultures as determined by SRB assay. To obtain growth curves, cells were plated on 96-well plates at a density of $5 \times 10^{3}$ cells per well. Cells were fixed for SRB assay at $24 \mathrm{~h}$ intervals starting $24 \mathrm{~h}$ after initial plating (12 technical replicates for each time-point). A surrogate of total cell numbers at each time-point was determined as absorbance value in SRB assay. The error bars show standard deviations.

The PDT in control cultures were significantly less $(p<$ $0.001)$ than in post-treatment cultures $(27.73 \pm 0.36 \mathrm{~h}$ and $37.46 \pm 0.17 \mathrm{~h}$, respectively), i.e. the cellular population that survived doxorubicin treatment displayed delayed and/or slower growth.

Sensitivity of MDA-MB-231 to cytotoxic substances after doxorubicin treatment. To assess the impact of pulsed doxorubicin treatment on the sensitivity of MDA-MB-231 cells to doxorubicin, cisplatin, vinblastine and 5-fluorouracil, a cytotoxicity test was performed in control and DOX +1 cultures (Fig. 6). Based on both GR50 and IC50 values, control and post-treatment cultures were more sensitive to vinblastine and doxorubicin (values in nanomolar range) than to cisplatin and 5-fluorouracil (values in micromolar range) (Table 3). Pulsed treatment with DOX resulted in increased resistance to doxorubicin in the DOX +1 cultures $\left(\mathrm{GR}_{50}\right.$ of 285.6 and $543.1 \mathrm{nM}$ in control and DOX+1 cultures, respectively; fold change of 1.9). This increase in resistance to doxorubicin was accompanied by increased sensitivity to cisplatin, vinblastine and 5-fluorouracil (sensitivity fold change values of $0.85,0.53$ and 0.69 , respectively).
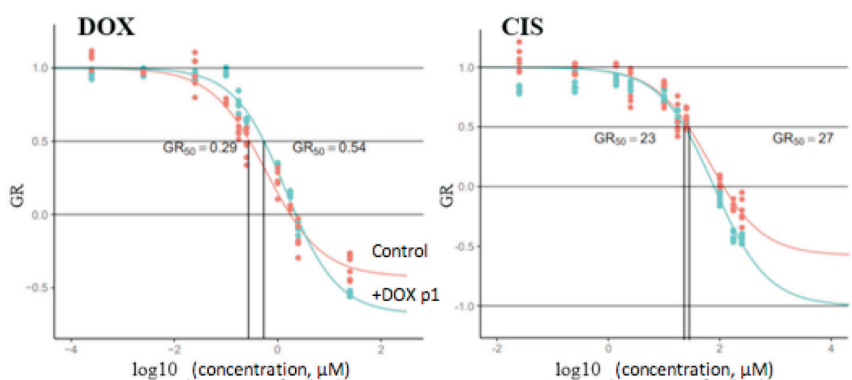

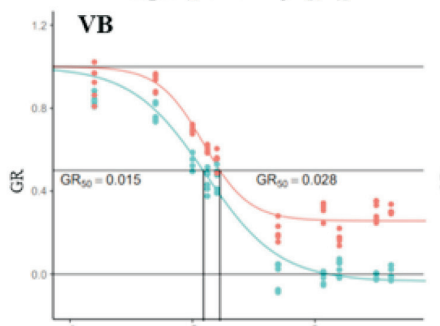

$\log 10$ (concentration, $\mu \mathrm{M}$ )

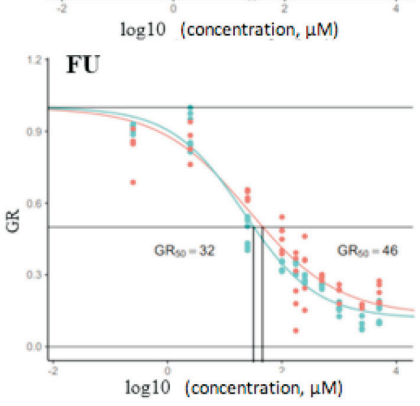

Fig. 6. The sensitivity of control cultures (red) and post-treatment $(\mathrm{DOX}+1)$ (blue) cultures of MDA-MB-231 to the tested cytotoxic compounds (doxorubicin (DOX), cisplatin (CIS), vinblastine (VB), 5-fluorouracil (FU)) after pulsed treatment with doxorubicin. Automatically calculated $\mathrm{R}^{2}$ for all simulated regressions was $\geq 0.95$.

Interestingly, adjustment of sensitivity metrics for growth rate $\left(\mathrm{GR}_{50}\right)$ (Hafner et al., 2016) as compared to the traditional cytotoxicity estimation $\left(\mathrm{IC}_{50}\right)$ revealed increased sensitivity to the tested substances (by factor of 1.50 to 3.50) and also showed that the sensitivity of post-treatment cultures to cisplatin, vinblastine and 5-fluorouracil actually decreased (Table 3, comparison of $\mathrm{GR}_{50}$ and $\mathrm{IC}_{50}$ values). The apparent increase of resistance to cisplatin, vinblastine and 5-fluorouracil as estimated by traditional $\mathrm{IC}_{50}$ values reflect only delayed or slower growth of post-treatment cultures as compared to controls, i.e. non-specific reduction of sensitivity.

Changes of the stem-like properties in MDA-MB-231 cell cultures after doxorubicin treatment and in posttreatment culture. Two methods were used to determine the effects of pulsed treatment with doxorubicin on stemlike properties in the studied breast cancer cell line MDAMB-231: changes in the transcriptomic expression of stemness-associated genes and long-term colony formation assay. Pulsed treatment with doxorubicin led to significant 
GR $_{50}$ AND IC 50 CONCENTRATION VALUES ( \pm STANDARD DEVIATION) FOR TESTED SUBSTANCES IN CONTROL CULTURES (UNTREATED CELLS) AND POST-TREATMENT CULTURES

\begin{tabular}{|c|c|c|c|c|}
\hline \multirow[t]{2}{*}{ Compound } & \multirow[t]{2}{*}{ Cytotoxicity metric } & \multicolumn{2}{|c|}{ Culture } & \multirow[t]{2}{*}{ Fold change } \\
\hline & & control culture & post-treatment culture & \\
\hline \multirow[t]{2}{*}{ Doxorubicin } & $\mathrm{GR}_{50} \pm \mathrm{SD}, \mathrm{nM}$ & $285.61 \pm 119.74$ & $543.08 \pm 115.37$ & 1.90 \\
\hline & $\mathrm{IC}_{50} \pm \mathrm{SD}, \mathrm{nM}$ & $439.76 \pm 162.23$ & $1133.30 \pm 300.49$ & 2.58 \\
\hline \multirow[t]{2}{*}{ Cisplatin } & $\mathrm{GR}_{50} \pm \mathrm{SD}, \mu \mathrm{M}$ & $27.27 \pm 9.18$ & $23.30 \pm 3.73$ & 0.85 \\
\hline & $\mathrm{IC}_{50} \pm \mathrm{SD}, \mu \mathrm{M}$ & $40.97 \pm 10.99$ & $43.65 \pm 5.58$ & 1.07 \\
\hline \multirow[t]{2}{*}{ Vinblastine } & $\mathrm{GR}_{50} \pm \mathrm{SD}, \mathrm{nM}$ & $28.00 \pm 7.01$ & $14.92 \pm 5.29$ & 0.53 \\
\hline & $\mathrm{IC}_{50} \pm \mathrm{SD}, \mathrm{nM}$ & $65.38 \pm 44.03$ & $70.98 \pm 17.76$ & 1.09 \\
\hline \multirow[t]{2}{*}{ 5-fluorouracil } & $\mathrm{GR}_{50} \pm \mathrm{SD}, \mu \mathrm{M}$ & $46.40 \pm 28.71$ & $32.21 \pm 10.95$ & 0.69 \\
\hline & $\mathrm{IC}_{50} \pm \mathrm{SD}, \mu \mathrm{M}$ & $161.88 \pm 103.49$ & $266.92 \pm 90.74$ & 1.65 \\
\hline
\end{tabular}

The cytotoxicity assay was performed at the passaging of the respective culture

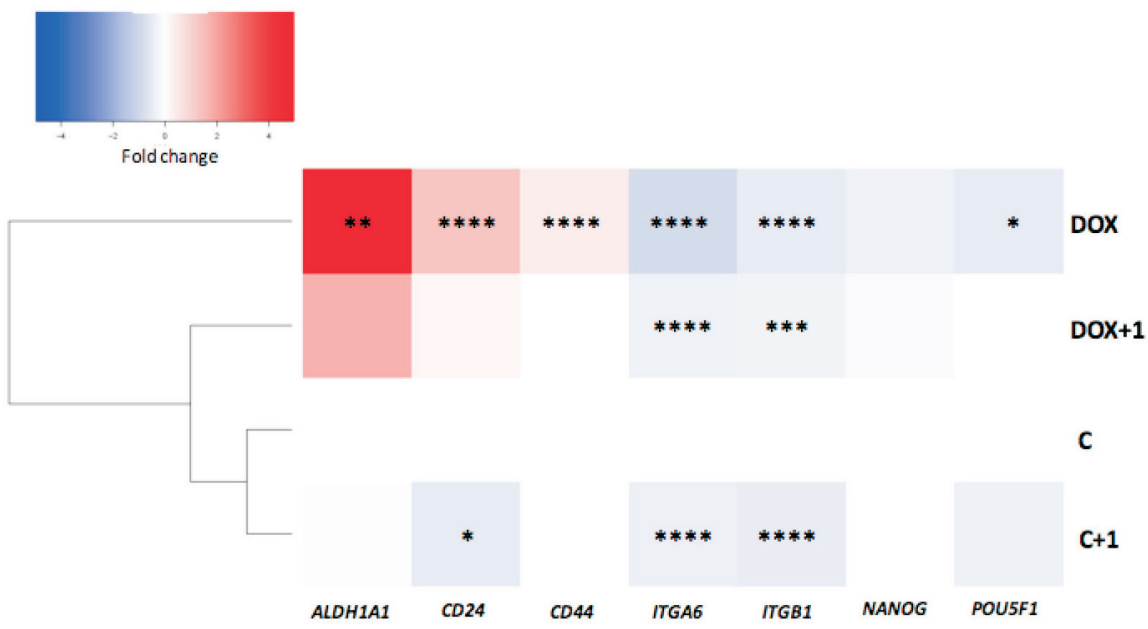

Fig. 7. Transcriptional expression of genes associated with stem-like properties using delta Ct obtained after relative quantification with real-time qPCR. Genes are shown on bottom part of heat map. On the right part of heat map the names of samples are indicated. Fold change is transformed in natural logarithmic scale and is relative to the control culture (C). Differences in comparison to the control at significance level $p<0.05$ are marked by $(*), p<0.01-(* *), p<0.001-(* * *)$, $p<0.0001-(* * *)$.

increase in the transcriptional expression of $A L D H 1 A$, $C D 24, C D 44$ genes and decrease in ITGA6, ITGB1 and POU 5F1 genes during the acute post-treatment phase (DOX treated cultures) (Fig. 7). Recovery phase (DOX+1 cultures) was characterised by decrease (partial normalization) of the transcriptomic expression levels for all tested genes. A statistically significant decrease in the transcriptomic expression of CD24, ITGA6 and ITGB1 genes was observed also in the second passage (Control+1 cultures) as compared to the first passage (control cultures) cells.

Pulsed doxorubicin treatment resulted also in statistically significant increase of colony formation ability in DOX +1 cultures by $58.4 \%$ as compared to control cultures (colony formation ability of $48.8 \pm 12.0 \%$ and $30.8 \pm 9.5 \%$, respectively) (Fig. 8).

\section{DISSCUSION}

Pulsed treatment of MDA-MB-231 with doxorubicin. Models of cell culture are the standard approach for in vitro chemotherapy resistance studies. Cell culture allows to determine the cellular response to the effects of chemotherapeutic compounds, and to develop cells with acquired resis-

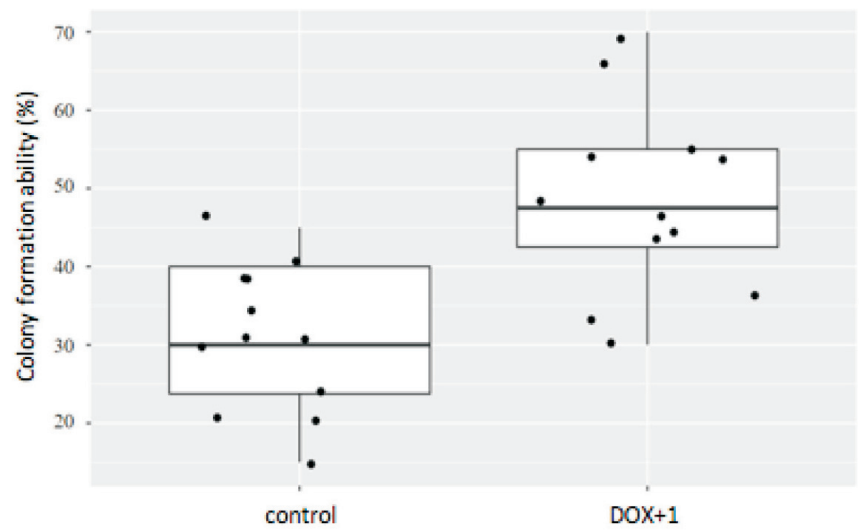

Fig. 8. Comparison of colony formation ability in MDA-MB-231 control cultures and post-treatment cultures after pulsed doxorubicin treatment.

tance by single or multiple exposure to the drugs (McDermott et al., 2014). To select for clinically relevant subpopulations and to develop multi-resistant cell lines, cells cultures are exposed to relatively low concentrations of cytotoxic compounds in a pulsed or continuous manner, thus simulating chemotherapy cycles (McDermott et al., 2014). For this study, a few pilot experiments (data not 
shown) were conducted to determine the doxorubicin $\mathrm{IC}_{50}$ for untreated MDA-MB-231 cells. The identified inhibitory concentration $(0.26 \mu \mathrm{M})$ was used for the pulsed treatment of MDA-MB-231 cells.

Changes in cellular morphology and proliferation rate after pulsed treatment with doxorubicin. One of the primary observations in cultures treated with doxorubicin was not only the increased numbers of suspension cells, but also increased numbers of the giant cells. These observations are in line with the reports showing spontaneous formation of polyploid giant cells in increasing numbers after treatment of cancer cell lines with cytotoxic compounds (Mirzayans et al., 2018). Cytotoxic compounds induce cell death; however, adaptive response can be initiated in some cells allowing them to survive (Holohan et al., 2013). In our experiment formation of giant cells with one enlarged nucleus or with multiple nuclei after doxorubicin treatment in MDAMB-231 cultures was observed. Other studies have shown that giant cells possess properties of CSCs - slow proliferation or lack of proliferation, growth arrest due to stress, and the ability to re-enter the cell cycle afterwards (Weihua et al., 2011). It has been shown that the giant cells that divide amitotically can promote stemness, giving the rise to new cells with stem-like features via various mechanisms - nuclear budding or bursting, depolyploidisation, horizontal transfer of a "sub-genome" between cells. The division of giant cells, termed neosis (Sundaram et al., 2004), has been observed in several mammalian cancer, including breast cancer, cell lines (Fei et al., 2015). Thus, in response to chemotherapy-induced stress, giant cells may initiate genomic re-organisation and give rise to new tumourinitiating cells, contributing to the relapse of the disease (Niu et al., 2016). Giant cells have demonstrated aggressiveness, increased resistance to cytotoxic compounds (including doxorubicin), capacity for colony-formation and metastases (Weihua et al., 2011; Mirzayans et al., 2018).

The growth dynamics of doxorubicin-treated MDA-MB231 cultures in our study is similar to the findings of other in vitro studies. For example, a study with a TP53-mutated cervical cancer cell line exposed to radiation showed increase in numbers of the giant polyploid cells. However, only approximately $2 \%$ of those cells were capable avoiding cell death and restoring the cellular population (Erenpreisa et al., 2008). Similarly, we observed increased numbers of the giant cells along with increased proportion of dying cells in our cultures along with the formation and clustering of small cells on top of the giant cells.

Re-growth of the population of the MDA-MB-231 cells after treatment with doxorubicin was due to formation of cellular colonies. In the post-treatment cultures $(\mathrm{DOX}+1)$, colonies and cells with mesenchymal-like morphology were observed. Recovery of the MDA-MB-231 cultures after treatment with doxorubicin was slow as evidenced by larger PDTs of post-treatment $(\mathrm{DOX}+1)$ cultures, and colony formation in the post-treatment cultures was observed from day 10 after treatment; on day 16 in the post-treatment $(\mathrm{DOX}+1)$ culture the count of cellular colonies was 55 (cor- responding to $0.011 \%$ of the seeded cells). This can be explained by increased numbers of giant polyploid cells. Several studies have shown the ability of the giant cells to stimulate epithelial-mesenchymal transition with possible influence on the development of metastasis and resistance to chemotherapeutic compounds (Mirzayans et al., 2018). (Mirzayans et al., 2018).

\begin{abstract}
Alterations of MDA-MB-231 sensitivity to cytotoxic compounds after doxorubicin treatment. Cell-growth assays (such as viability and clonogenicity tests) are used to detect cellular sensitivity to chemotherapeutic compounds (McDermott et al., 2014; Mckenna et al., 2017). Multiresistance can be induced by various mechanisms (Dean et al., 2001), therefore the sensitivity of cells is tested against several chemotherapy compounds. The sensitivity of posttreatment cultures to several compounds was measured and compared to the control cultures. In addition to doxorubicin, we used several additional cytotoxic compounds: vinblastine (VB) that inhibits cell division through microtubule inhibition (Gottesman et al., 2002); cisplatin (CIS) that causes DNA crosslinking inhibiting DNA reparation (Dasari and Tchounwou, 2014); and 5-fluorouracil (FU) that is a nucleotide analogue inhibiting tymidylate synthase and therefore DNA and RNA synthesis (Hu et al., 2018). All these compounds are substrates for multi-resistance associated transporters of the ABC family (Gottesman et al., 2002).
\end{abstract}

The growth rate metrics $\left(\mathrm{GR}_{50}\right)$ used in this study estimate the concentration of the compound that inhibits cellular growth rate by $50 \%$ after adjustment for growth rate, i.e., the number of cell divisions and the seeding density has no effect on this parameter (Hafner et al., 2016; 2017). Based on $\mathrm{GR}_{50}$ values, our doxorubicin-treated cultures showed an increase of resistance only to doxorubicin. These data are in line with the literature (Kibria et al., 2014). The development of increased resistance to doxorubicin can be explained by the selection of the population adapted to a particular stress and by genetic and/or epigenetic changes enabling effective survival. Since sensitivity to the other tested compounds increased, it can be suggested that the post-treatment cultures were re-generated by a part of the cellular population exhibiting anti-doxorubicin specific mechanisms.

The $\mathrm{IC}_{50}$ value is a traditionally used metric of cytotoxicity estimating concentration of a compound that inhibits the cell division rate by $50 \%$, and it is not adjusted for growth rates of the culture. Unlike $\mathrm{GR}_{50}$ values, all $\mathrm{IC}_{50}$ values for our post-treatment cultures indicated an increase of resistance to all tested cytotoxic compounds. While $\mathrm{IC}_{50}$ values are traditionally used for assessment of cytotoxicity, they are difficult to reproduce (Hafner et al., 2017) and depend on the culture division times (PDTs). PDTs differ for various cell types and can be influenced by stress factors and cellular responses. In our post-treatment cultures PDTs were higher than in the control cultures; therefore the obtained $\mathrm{IC}_{50}$ values reflect mainly a reduction of culture growth rates, not the development of multi-resistance. Since the $\mathrm{R}$ programme package GRmetrics does not estimate the 
statistical significance for $\mathrm{IC}_{50}$ and $\mathrm{GR}_{50}$ values, additional calculations for assessing sensitivity changes could be beneficial. However, the authors of $\mathrm{GR}_{50}$ method have demonstrated the incompleteness of $\mathrm{IC}_{50}$ values in data from a large-scale cell line and a chemotherapy compound data base (Genentech Cell Line Screening Initiative gCSI) and showed statistically significant $(p<0.001)$ correlation between sensitivity to the compound and PDTs (Hafner et al., 2016, 2017).

In our study sulforhodamine B (SRB) assay was used as a surrogate whole-well endpoint colorimetric assay to determine cell counts for population doubling time and cytotoxicity assessment. SRB binds to cellular proteins and the amount of bound dye is proportional to the number of cells if their size in the culture does not change. Morphology of cells, including their size, in post-treatment cultures differed not only from the controls, but was heterogeneous within the same culture. Therefore, we cannot exclude that the doxorubicin-induced alterations of cellular morphology and dimensions in post-treatment cultures interfered with the estimations and comparisons of PDTs and cytotoxicity due to the nature of SRB assay. Each tumour cell and/or subpopulation of cells responds to a particular cytotoxic compound differently (Leggett et al., 2016), therefore a better method to determine sensitivity and cell counts for cytotoxicity assays would be a direct count of cells (and/or nuclei) by immunofluorescence microscopy or flow cytometry.

Changes of the stem-like properties in MDA-MB-231 cell cultures after doxorubicin treatment and in posttreatment culture. The properties of cancer stem-like cells (sSLC) in cultures exposed to doxorubicin were measured by long-term clonogenity assay and assessment of transcriptomic expression of several stemness-marker genes. There are no known unique and specific breast cSLC markers up to this day, and many studies use potential markers, such as CD44, CD24, ALDH1A1 (Al-Hajj et al., 2003). HwangVerslues et al., 2009 showed a high variability of stemnessmarker expression in different breast cancer cell lines. However, their study detected a highly tumorigenic $\mathrm{PROCR}^{+} / \mathrm{ESA}^{+}$cell population in basal breast cancer cell line MDA-MB-231.

$\mathrm{CD} 44^{+} / \mathrm{CD} 24^{\text {low } /-}$ is one of the most studied breast cancer cell populations that is capable of tumour initiation and metastases, and results in adverse treatment outcomes (Sheridan et al., 2006; Deng et al., 2017). It has been shown (Deng et al., 2017) that in comparison to other triple negative breast cancer cell lines, MDA-MB-231 consists mostly of $\mathrm{CD} 44^{+} / \mathrm{CD} 24^{-}$cells with a relatively high resistance to doxorubicin and other anthracyclines. Our doxorubicin treated cultures displayed elevated transcriptional expression levels of both $C D 44$ and especially of $C D 24$ during the acute post-treatment period (DOX cultures), and returned to control levels during the recovery phase $(\mathrm{DOX}+1)$. The effects of various treatment modalities can depend on CD44/CD24 status of the cells, e.g., radiation-induced apoptosis was less pronounced in the pancreatic ductal adenocarcinoma-derived cell line fraction that consisted of
$\mathrm{CD} 44^{+} / \mathrm{CD} 24^{+}$cells (Wang et al., 2017). Our study indicates that doxorubicin has a short-term effect on the transcriptional expression of CD44, CD24 and ALDH1A1.

ITGA6 and ITGBI are genes of the integrin family, and elevated expression of both genes has been associated with the cSLC phenotype, tissue invasion and capability for metastasis (Brooks et al., 2016; Kim and Ryu, 2017). Vassilopoulos et al. (2013) showed in vivo the tumour initiation properties of ITGA6+/ITGB1+/CD24+ cell populations. In our cultures, transcriptional expression of both genes decreased after the treatment with doxorubicin. This can be explained by increasing numbers of suspension cells after treatment, since both integrins are adhesion molecules. Post-treatment cultures displayed return of the expression levels of integrins to pre-treatment levels equivalent to the control cultures.

Changes in transcriptional expression of ALDHIAl were observed in treated cultures. ALDHIA is another marker widely associated with the CSC phenotype; it has been associated with chemoresistance and has been shown to correlate with the outcome of treatment (El-Badawy et al., 2017). In our control and post-treatment (DOX+1) MDA-MB-231 cultures the expression of ALDHIAl was reduced, whereas a high expression was detected in the treated cultures (DOX). Elevated ALDHIAl levels along with embryonic stem cell markers, have been observed in paclitaxel resistant MDA-MB-231 cells previously (Liu et al., 2013). However, in our doxorubicin treated cultures, no elevated expression levels of the embryonic stem cell markers $N A N O G$ and POU5F1 (Oct3/4) were observed.

Embryonic stem cell markers are expressed in breast cancer cell lines (Ling et al., 2012). Expression of both POU5F1 $(\mathrm{Oct} 3 / 4)$ and NANOG has been associated with chemoresistance in a breast cancer stem cell fraction isolated by enrichment of MDA-MB-231 (Huang et al., 2015). In our study, the transcriptional expression levels of POU5F1 (Oct3/4) slightly decreased in treated cultures, but returned to control levels in post-treatment cultures, suggesting that doxorubicin has no significant effect on the expression of embryonic stem cell markers, and perhaps putative cancer stem-like cell population enrichment could be one procedure to obtain an intrinsically chemoresistant fraction of breast cancer cell lines.

The characteristic ability of CSCs to regenerate the population was observed in post-treatment $(\mathrm{DOX}+1)$ culture - the recovery was provided by a relatively small number of cells (Weihua et al., 2011). During post-treatment (DOX+1) cultures we observed non-adherent cell clusters resembling CSCs that have been described in several mammosphere studies (Jia et al., 2016; El-Badawy et al., 2017). Long-term colony formation assay showed a significantly increased capability of post-treatment $(\mathrm{DOX}+1)$ cultures to form colonies in comparison to control cells, and this observation is in line with other studies of giant cells with CSC features (Weihua et al., 2011). 
Overall, transcriptional expression of several genes associated with CSCs along with the results of long-term colony formation assay suggest that treatment with doxorubicin selected the fraction of MDA-MB-231 cells exhibiting some stem-like features and increased ability to regenerate the cellular population. In the future, perhaps, a CSC enriched population could be better model to study multidrug resistance mechanisms in vitro.

\section{CONCLUSIONS}

In summary, a subpopulation of the doxorubicin resistant cells along with doxorubicin sensitive cells survived pulsed treatment with doxorubicin in the breast cancer cell line MDA-MB-231. Although the transcriptional expression levels of some stemness-associated marker genes increased, it was difficult to show that the proportion of cancer stem-like cells in cell culture has increased after the doxorubicin treatment. The heterogeneous culture after the doxorubicin treatment included giant cells along with suspension cells that had higher capacity to regenerate the population, indicating a correlation between the development of resistance and the selection of more aggressive and viable cancer cells.

\section{ACKNOWLEDGEMENTS}

This research was supported by the Latvian National Research Programme "Biomedicine for Public Health (BIOMEDICINE)", project No.5.5 "Personalized cancer diagnostics and prediction of therapy efficacy".

\section{REFERENCES}

Achuthan, S., Santhoshkumar, T. R., Prabhakar, J., Nair, S. A., Pillai, M. R. (2011). Drug-induced senescence generates chemoresistant stemlike cells with low reactive oxygen species. J. Biol. Chem., 286 (43), 37813-37829.

Al-Hajj, M., Wicha, M. S., Benito-Hernandez, A., Morrison, S. J., Clarke, M. F. (2003). Prospective identification of tumorigenic breast cancer cells. Proc. Natl. Acad. Sci. USA, 100 (7), 3983-3988.

Anonymous (2018). R: A Language and Environment for Statistical Computing. $\mathrm{R}$ foundation for statistical computing, Vienna. Available from: https://www.R-project.org/ (accessed 20.01.2019)

Brooks, D. L. P., Schwab, L. P., Krutilina, R., Parke, D. N., Sethuraman, A., Hoogewijs, D., Schörg, A., Gotwald, L., Fan, M., Wenger, R. H., Seagroves, T. N. (2016). ITGA6 is directly regulated by hypoxia- inducible factors and enriches for cancer stem cell activity and invasion in metastatic breast cancer models. Mol. Cancer, 15, 26.

Cortós-Funes, H., Coronado, C. (2007). Role of anthracyclines in the era of targeted therapy. Cardiovasc. Toxicol., 7 (2), 56-60.

Cox, J., Weinman, S. (2016). Mechanisms of doxorubicin resistance in hepatocellular carcinoma. Hepat Oncol., 3 (1), 57-59.

Dasari, S., Tchounwou, P. B. (2014). Cisplatin in cancer therapy: Molecular mechanisms of action. Eur. J. Pharmacol., 740, 364-378.

Dean, M., Fojo, T., Bates, S. (2005). Tumour stem cells and drug resistance. Nat. Rev. Cancer, 5 (4), 275-284

Dean, M., Hamon, Y., Chimini, G. (2001). The human ATP-binding cassette transporter superfamily. J. Lipid Res., 42 (7), 1007-1017.

Deng, X., Apple, S., Zhao, H., Song, J., Lee, M., Luo, W., Wu, X., Chung, D., Pietras, R. J., Chang, H. R. (2017) CD24 expression and differential resis- tance to chemotherapy in triple-negative breast cancer. Oncotarget, 8(24), 38294-38308

El-Badawy, A., Ghoneim, M. A., Gabr, M. M., Salah, R. A., Mohamed, I. K., Amer, M., El-Badri, N. (2017). Cancer cell-soluble factors reprogram mesenchymal stromal cells to slow cycling, chemoresistant cells with a more stem-like state. Stem Cell Res. Ther., 8 (1), 254.

Erenpreisa, J., Ivanov, A., Wheatley, S. P., Kosmacek, E. A., Ianzini, F., Anisimov, A. P., Mackey, M., Davis, P. J., Illidge, T. M. (2008). Endopolyploidy in irradiated p53-deficient tumour cell lines: Persistence of cell division activity in giant cells expressing Aurora-B kinase. Cell Biol. Int., 32 (9), 1044-1056.

Fei, F., Zhang, D., Yang, Z., Wang, S., Wang, X., Wu, Z., Wu, Q., Zhang, S. (2015). The number of polyploid giant cells and epithelial-mesenchymal transition-related proteins are associated with invasion and metastasis un human breast cancer. J. Exp. Clin. Cancer Res., 34, 158.

Freshney, R. I. (2011). Culture of Animal Cells: A Manual of Basic Technique and Specialized Applications. Hoboken, NY.: Wiley-Blackwell. 728 pp.

Gewirtz, D. A. (1999). A critical evaluation of the mechanisms of action proposed for the antitumor effects of the anthracycline antibiotics adriamycin and daunorubicin. Biochem. Pharmacol., 57 (7), 727-741.

Gottesman, M. M., Fojo, T., Bates, S. E. (2002). Multidrug resistance in cancer: Role of ATP-dependent transporters. Nat. Rev. Cancer, 2 (1), 48-58.

Hafner, M., Niepel, M., Chung, M., Sorger, P. K. (2016). Growth rate inhibition metrics correct for confounders in measuring sensitivity to cancer drugs. Nat. Methods, 13 (6), 521-527.

Hafner, M., Niepel, M., Sorger, P. K. (2017). Alternative drug sensitivity metrics improve preclinical cancer pharmacogenomics. Nat. Biotechnol., 35 (6), 52-54.

Holohan, C., Van Schaeybroeck, S., Longley, D. B., Johnston, P. G. (2013). Cancer drug resistance: An evolving paradigm. Nat. Rev. Cancer, 13 (10), 714-726.

Hu, H., Wang, M., Guan, X., Yuan, Z., Liu, Z., Zou, C., Guiyu, W., Gao, X., Wang, X. (2018). Loss of ABCB4 attenuates the caspase-dependent apoptosis regulating resistance to 5-Fu in colorectal cancer. Biosci Rep., 38 (1), BSR20171428.

Huang, Z. J., You, J., Luo, W. Y., Chen, B. S., Feng, Q. Z., Wu, B. L., Jiang, L., Luo, Q. (2015). Reduced tumorigenicity and drug resistance through the downregulation of octamer-binding protein 4 and Nanog transcriptional factor expression in human breast stem cells. Mol. Med. Rep., 11 (3), 1647-1654.

Hwang-Verslues, W. W., Kuo, W. H., Chang, P. H., Pan, C. C., Wang, H. H., Tsai, S. T., Jeng, Y. M., Shew, J. Y., Kung, J. T., Chen, C. H., Lee, E. Y., Chang, K. J., Lee, W. H. (2009). Multiple lineages of human breast cancer stem/progenitor cells identified by profiling with stem cell markers. PLoS ONE, 4 (12), e8377.

Jia, D., Tan, Y., Liu, H., Ooi, S., Li, L., Wright, K., Bennett, S., Addison, C.L., Wang, L. (2016). Cardamonin reduces chemotherapy-enriched breast cancer stem-like cells in vitro and in vivo. Oncotarget, 7 (1), 771-785.

Kibria, G., Hatakeyama, H., Akiyama, K., Hida, K., Harashima, H. (2014) Comparative study of the sensitivities of cancer cells to doxorubicin, and relationships between the effect of the drug-efflux pump P-gp. Biol. Pharm. Bull., 37 (12), 1926-1935.

Kim, W., Ryu, C. J. (2017). Cancer stem cell surface markers on normal stem cells. BMB Rep., 50 (6), 285-298.

Leggett, S. E., Sim, J. Y., Rubins, J. E., Neronha, Z. J., Williams, K., Wong, I. Y. (2016). Morphological single cell profiling of the epithelial-mesenchymal transition. Integr. Biol. (Camb)., 8 (11), 1133-1144.

Liang, Y., Zhong, Z., Huang, Y., Deng, W., Cao, J., Tsao, G., Liu, Q., Pei, D., Kang, T., Zeng, Y.X. (2010). Stem-like cancer cells are inducible by increasing genomic instability in cancer cells. J. Biol. Chem., 285 (7), 4931-4940. 
Ling, G. Q., Chen, D. B., Wang, B. Q., Zhang, L. S. (2012). Expression of the pluripotency markers Oct3/4, Nanog and Sox 2 in human breast cancer cell lines. Oncol. Lett., 4 (6), 1264-1268.

Liu, P., Kumar, I. S., Brown, S., Kannappan, V., Tawari, P. E., Tang, J. Z., Jiang, W., Armesilla, A. L., Darling, J. L., Wang, W. (2013). Disulfiram targets cancer stem-like cells and reverses resistance and cross-resistance in acquired paclitaxel-resistant triple-negative breast cancer cells. Brit. J. Cancer, 109 (7), 1876-1885.

Livak, K. J., Schmittgen, T. D. (2001). Analysis of relative gene expression data using real-time quantitative PCR and the 2(-delta delta $\mathrm{C}(\mathrm{T})$ ) method. Methods, 25 (4), 402-408.

McDermott, M., Eustace, A. J., Busschots, S., Breen, L., Crown, J., Clynes, M., O'Donovan N., Stordal, B. (2014). In vitro development of chemotherapy and targeted therapy drug-resistant cancer cell lines: A practical guide with case studies. Front. Oncol., 4, 40.

Mckenna, M. T., Weis, J. A., Barnes, S. L., Tyson, D. R., Miga, I., Quaranta, V., Yankeelov, T. E. (2017). Modeling approach for the study of doxorubicin treatment in triple negative breast cancer. Sc. Rep., 7 (1), 5725.

Mirzayans, R., Andrais, B., Murray, D. (2018). Roles of polyploid/ multinucleated giant cancer cells in metastasis and disease relapse following anticancer treatment. Cancers, 10, 118.

Moitra, K., Lou, H., Dean, M. (2011). Multidrug efflux pumps and cancer stem cells: Insights into multidrug resistance and therapeutic development. Clin. Pharmacol. Ther., 89 (4), 491-502.

Niu, N., Zhang, J., Zhang, N., Mercado-Uribe, I., Tao, F., Han, Z., Pathak, S., Multani, A. S., Kuang, J., Yao, J., Bast, R.C., Sood, A.K., Hung, M.-C., Liu, J. (2016). Linking genomic reorganization to tumor initiation via the giant cell cycle. Oncogenesis, 5, e281.

Nowell, P. C. (1976). The clonal evolution of tumor cell populations. Science, 194 (4260), 23-28.

Rajaraman, R., Guernsey, D. L., Rajaraman, M. M., Rajaraman, S. R. (2006). Stem cells, senescence, neosis and self-renewal in cancer. Cancer Cell Int., 6, 1-26.

Rivera, E., Gomez, H. (2010). Chemotherapy resistance in metastatic breast cancer: The evolving role of ixabepilone. Breast Cancer Res., 12 (Suppl 2), S2.

Saxena, M., Stephens, M. A., Pathak, H., Rangarajan, A. (2011). Transcription factors that mediate epithelial-mesenchymal transition lead to multidrug resistance by upregulating ABC transporters. Cell Death Dis., 2, e179.

Received 7 November 2018

Accepted in the final form 6 February 2019
Sheridan, C., Kishimoto, H., Fuchs, R. K., Mehrotra, S., Bhat-Nakshatri, P., Turner, C. H., Goulet, R. Jr., Badve, S., Nakshatri, H. (2006). CD44+/CD24-Breast cancer cells exhibit enhanced invase properties: An early step necessary for metastasis. Breast Cancer Res., 8 (5), R59.

Skehan, P., Storeng, R., Scudiero, D., Monks, A., Vistica, D., Warren, J. T., Bokesch, H., Kenney, S., Boyd, M. R. (1990). New colorimetric cytotoxicity assay for anticancer-drug screening. J. Natl. Cancer Inst., 82 (13), 1107-1112.

Smith, L. Watson, M. B., O'Kane, S. L., Drew, P. J., Lind, M. J., Cawkwell, L. (2006). The analysis of doxorubicin resistance in human breast cancer cells using antibody microarrays. Mol. Cancer Ther., 5 (8), 2115-2120.

Sun, L., Cabarcas, S. M., Farrar, W. L. (2012). Radioresistance and cancer stem cells: Survival of the fittest. J. Carcinogene Mutagenes, s1(01), 1-12.

Sundaram, M., Guernsey, D. L., Rajaraman, M. M., Rajaraman, R. (2004) Neosis: A novel type of cell division in cancer. Cancer Biol. Ther., 3 , 2017-2218.

Tegze, B., Szállási, Z., Haltrich, I., Pénzváltó, Z., Tóth, Z., Likó, I., Gyorffy, B. (2012). Parallel evolution under chemotherapy pressure in 29 breast cancer cell lines results in dissimilar mechanisms of resistance. PLoS ONE, 7 (2), 1-9.

Vassilopoulos, A., Chisholm, C., Lahusen, T., Zheng, H., Deng, C. (2013). A critical role of CD29 and CD49f in mediating metastasis for cancer-initiating cells isolated from a Brcal-associated mouse model of breast cancer. Oncogene, 33 (47), 5477-5482.

Vichai, V., Kirtikara, K. (2006). Sulforhodamine B colorimetric assay for cytotoxicity screening. Nature Protocols, 1 (3), 1112-1116.

Vinogradov, S., Wei, X. (2012). Cancer stem cells and drug resistance: The potential of nanomedicine. Nanomedicine (Lond)., 7 (4), 597-615.

Wang, L., Li, P., Hu, W., Xia, Y., Hu, C., Liu, L., Jiang, X. (2017). CD44 + CD24 + subset of PANC-1 cells exhibits radiation resistance via decreased levels of reactive oxygen species. Oncol. Lett., 14 (2), 1341-1346.

Weihua, Z., Lin, Q., Ramoth, A. J., Fan, D., Fidler, I. J. (2011). Formation of solid tumors by a single multinucleated cancer cell. Cancer, 117 (17), 4092-4099.

Xiang, D., Shigdar, S., Bean, A. G., Bruce, M., Yang, W., Mathesh, M., Wang, T., Yin, W., Tran, P. H., Al Shamaileh, H., Barrero, R. A., Zhang, P. Z., Li, Y., Kong, L., Liu, K., Zhou, S. F., Hou, Y., He, A., Duan, W. (2017) Transforming doxorubicin into a cancer stem cell killer via EpCAM aptamer-mediated delivery. Theranostics., 7 (17), 4071-4086.

Zhang, S., Mercado-Uribe, I., Xing, Z., Sun, B., Kuang, J., Liu, J. (2014) Generation of cancer stem-like cells through the formation of polyploid giant cancer cells. Oncogene, 33 (1), 116-128.

\section{PUNKTVEIDA APSTRĀDES AR DOKSORUBICĪNU IETEKME UZ CILMESTĪBAS İPAŠĪBĀM KRŪTS VĒĚA ŠŪNU LĪNIJĀ MDA-MB-231}

Vēža ārstēšanā būtiska problēma ir rezistences veidošanās pret ķīmijterapiju, kā rezultātā var attīstīties atkārtots audzējs. Vēža cilmes šūnām vai cilmes šūnām līdzīgām šūnām raksturīga gan dabiska, gan iegūta kị̄mijrezistence. Pētījuma mērḳis bija raksturot cilmestības raksturīgās pazīmes krūts vēža šūnu līnijā MDA-MB-231 pēc punktveida apstrādes ar doksorubicīnu (DOX). Eksperimentālās kultūras 48 stundas tika pakḷautas DOX iedarbībai terapeitiskā devā un kultivētas vēl 24 stundas pēc DOX aizvākšanas. Šūnu populācijas cilmestība tika novērtēta pēc cilmes šūnām raksturīgo markiergēnu ekspresijas (CD24, CD44, ITGA6, ITGB1, POU5F1, NANOG, ALDH1A1), koloniju veidošanās spējas, augšanas ātruma un jutîbu pret DOX, 5-fluorouracilu (FU), cisplatīnu (CIS) un vinblastīnu (VBL). Apstrāde ar DOX inducēja gigantisku, poliploīdu šūnu parādī̌̌anos kultūrā, kas saglabājās arī nākamajā pārsējumā un bija atbildīgas par populācijas atjaunošanos. Atlabšanas periodā šūnu kultūrā tika novērota proliferācijas, dzīvotspējas un šūnu adherences samazināšanās. Atjaunotās populācijas šūnas bija mazāk jutīgas pret DOX. Savukārt, jutība pret FU, CIS un VBL bija paaugstināta. DOX ietekmē paaugstinājās CD24, CD44 un ALDH1Al transkripcionālā ekspresija, kas atgriezās iepriekšējā līmenī šūnās pēc pārsēšanas. Šūnām pēc DOX apstrādes bija paaugstināta spēja veidot kolonijas. Vēža šūnu ar cilmes šūnām raksturīgām īpašībām veidošanās (vai selekcija) ir pamatā šūnu kultūras spējai izdzīvot pēc DOX ekspozīcijas un veidot atjaunotu šūnu populāciju. 